Skąpska E., Krajowy System Ustug jako podstawa przedsiębiorczości regionalnej, „Ekonomia i Prawo", Polszakiewicz B., Boehlke J. (red.), Tom XII, nr 1/2013, ss. 93-104 DOI: http://dx.doi. org/10.12775/EiP.2013.008

\author{
ELŻBIETA SKĄPSKA*
}

\title{
KRAJOWY SYSTEM USŁUG JAKO PODSTAWA PRZEDSIĘBIORCZOŚCI REGIONALNEJ
}

\section{STRESZCZENIE}

W odpowiedzi na rosnące zapotrzebowanie na nowe usługi dla biznesu powstał Krajowy System Usług (KSU), którego misją jest rozwój przedsiębiorczości poprzez zapewnienie najwyższej jakości usług w kluczowych obszarach wymagających wsparcia państwa. Za sprawą usług KSU tworząca się koniunktura aktywności przedsiębiorczej w regionie daje szansę na intensywny rozwój społeczno-gospodarczy. Za cel artykułu przyjęto zbadanie zaangażowania usług świadczonych przez ośrodki KSU w rozwój firm, a przez to również polskiego regionu jako płaszczyzny działań przedsiębiorczych, zwłaszcza o charakterze ekonomicznym.

Słowa kluczowe: Krajowy System Usług, przedsiębiorczość regionalna

Klasyfikacja JEL: D, O

\section{KSU (NATIONAL SERVICE SYSTEM) SERVICES AS BASIS OF REGIONAL ENTREPRENEURSHIP}

\section{SUMMARY}

In response to a growing demand for new business services, National Service System (Polish "KSU") has been founded. Its mission is the development of entrepreneurship

* Elżbieta Skąpska, Politechnika Białostocka, Wydział Zarządzania, Katedra Ekonomii i Nauk Społecznych, ul. Ojca Tarasiuka 2, 16-001 Kleosin, e-mail: elzbieta.skapska@onet.eu. 
by assuring the highest standard of services in the key fields where the government's support is required. Due to KSU services, the expanding trade cycle in an active region gives the chance for intense socio-economic development. The aim of this article is to examine the degree of involvement of KSU centers in company development, and as a result, in a Polish region development as a common ground for entrepreneurial activity, especially this of economic nature.

Keywords: National Service System (Polish "KSU"), regional entrepreneurship

JEL Classification: D, O

\section{WSTĘP}

Aktualnie nie da się osiągnąć rozwoju społeczno-gospodarczego bez budowania osi spójności w wymiarze przestrzennym oraz usługowej siły sprawczej. Nie można również zapomnieć, że istnieją odmienności regionalne, które dotyczą wielu aspektów: postaw, skłonności do ponoszenia ryzyka, umiejętności akceptacji zmian bądź pozostawania ortodoksyjnie wiernym tradycji, większych lub mniejszych umiejętności współdziałania i związanej z nimi przedsiębiorczości ${ }^{1}$.

Obserwuje się również dokonujący się w ciągu co najmniej dwóch dekad znaczący postęp w zakresie polskiej przedsiębiorczości. Jednakże należy zaznaczyć, że jej pozycja w tym względzie w stosunku do innych krajów UE jest co najmniej niewystarczająca. Jednym $z$ wyraźnych przejawów prorozwojowych zmian było powstanie sieci współpracujących ze sobą niekomercyjnych organizacji - Krajowego Systemu Usług (KSU), z inicjatywy Polskiej Agencji Rozwoju Przedsiębiorczości². Ważne jest, tak z punktu widzenia całej gospodarki, jak i jej poszczególnych regionów, aby przedsiębiorczość, rozumiana jako proces i jako cecha rozwijała się.

\section{PRZEDSIĘBIORCZOŚĆ W REGIONIE - EKONOMICZNE I POZAEKONOMICZNE WARUNKI ROZWOJU}

Mimo braku kompleksowej i jednolitej teorii oraz definicji przedsiębiorczości - zdaniem ekonomistów, zgodność dotyczy pojmowania aktywności

${ }^{1}$ E. Zeman-Miszewska, Przeksztatcenia instytucji regionalnych/lokalnych w Polsce (wybrane problemy), [w:] E. Okoń-Horodyńska (red.), Przedsiębiorczość jako niewykorzystane źródto sukcesu polskiej gospodarki, Polskie Towarzystwo Ekonomiczne, Warszawa 2009, s. 83.

${ }^{2}$ Dawniej: Polskiej Fundacji Promocji i Rozwoju Małych i Średnich Przedsiębiorstw. PARP powstała w 2001 r. jako instytucja rządowa od 2004 roku, realizująca programy wykorzystujące fundusze pomocowe Unii Europejskiej. 
przedsiębiorczej jako czynnika przyczyniającego się do rozwoju ekonomicznego całej gospodarki i pojedynczego przedsiębiorstwa.

Każda aktywność gospodarcza wymaga przestrzeni, która wiąże się z umiejętnością efektywnego zagospodarowania określonego regionu. Pojęcie to rozumiane jest jako terytorium określone historycznie lub kulturowo, obszary wyodrębnione na podstawie kryteriów organizacji administracyjnej i politycznej, a także używa się tego pojęcia do określenia przestrzeni ekonomicznej. Regiony ekonomiczne to obszary zwarte przestrzennie, terytorium spójne wewnętrznie i stanowiące kompleks o określonym profilu gospodarczym ${ }^{3}$.

Ważnym elementem konkurencyjności regionu jest więc bezdyskusyjnie istnienie dobrze zorganizowanych środowisk przedsiębiorczości. Mali i średni przedsiębiorcy koordynują działania wszystkich elementów zbioru tworzącego region ${ }^{4}$. Jego rozwój to nie tylko proces o charakterze gospodarczym, ale również trwały wzrost poziomu życia i dobrobytu jego mieszkańców. Tak więc, przedsiębiorczość w regionie należy rozpatrywać zarówno w sensie ekonomicznym, jak i pozaekonomicznym.

Zgodnie z kryterium NUTS ${ }^{5}$, na terytorium Polski wyróżniono 6 regionów. Są to ${ }^{6}$ : centralny, obejmujący województwa - łódzkie, mazowieckie; potudniowy: małopolskie, śląskie; wschodni: lubelskie, podkarpackie, podlaskie, świętokrzyskie; pótnocno-zachodni: lubuskie, wielkopolskie, zachodniopomorskie; potudniowo-zachodni: dolnośląskie, opolskie; pótnocny: kujawsko-pomorskie, pomorskie, warmińsko-mazurskie.

Kontynuując wątek regionu jako obszaru do rozwoju aktywności gospodarczej, warto zwrócić uwagę na to, iż transformacja pomysłu biznesowego w organizację wymaga od przyszłego przedsiębiorcy nabycia niezbędnych zasobów, choć samo nabycie nie gwarantuje sukcesu. Zasoby często powinny być połączone w nowy sposób, dzięki któremu uzyska on nową wartość dodaną, pozwalającą na osiągnięcie zysku ekonomicznego ${ }^{7}$. Zdaniem P. F. Druckera ${ }^{8}$ :

${ }^{3}$ A. Jagiełło, Region i jego rozwoój w warunkach globalizacji, [w:] D. J. Błaszczuk, M. Stefański (red.), Strategiczna problematyka rozwoju Polski Wschodniej, Wyższa Szkoła Ekonomii i Innowacji w Lublinie, Lublin 2010, s. 224.

${ }^{4}$ Ibidem.

5 Podział na regiony - według Eurostat, kryterium statystycznego NUTS (Nomenclature of Units for Territorial Statistics), odnoszącego się do prowadzenia jednolitej polityki regionalnej we wszystkich krajach członkowskich Unii Europejskiej.

${ }^{6}$ Bank Danych Lokalnych, Główny Urząd Statystyczny, http://www.stat.gov.pl, 09.06.2012.

7 S. L. Newbert, New Firm Formation: A Dynamic Capability Perspective, "Journal of Small Business Management", 2005, vol. 43 (1), s. 55-77.

${ }^{8}$ P. F. Drucker, Natchnienie i fart, czyli innowacja i przedsiębiorczośc, Wyd. Studio EMKA, Warszawa 2004, s. 34. 
„nie ma czegoś takiego jak «zasób», dopóki człowiek nie znajdzie dla niego zastosowania w przyrodzie i w ten sposób nada mu wartość ekonomiczną”.

Wśród praktycznych wyznaczników działań przedsiębiorczych wymienia się?:

- zdolność i zamiłowanie do pracy koncepcyjnej i przekształcenie jej $\mathrm{w}$ praktyczne działania w otoczeniu pracy;

- skłonność i umiejętność do podejmowania kalkulowanego ryzyka, opartego na analitycznej ocenie istniejącej sytuacji w krótkim przedziale czasowym;

- odporność psychiczną na niespodziewany sukces czy porażkę oraz twórcze analizowanie przesłanek, które doprowadziły do tej sytuacji;

- stałą gotowość do rywalizacji, zakładającą coraz większy stopień trudności w realizowaniu wyznaczonego celu.

Jak wynika $z$ badania przeprowadzonego przez Instytut Rynku Wewnętrznego i Konsumpcji w 2005 roku ${ }^{10}$, spośród różnych czynników wpływających na efektywne działanie firmy uznano za znaczące: zdolność, do rozwiązywania problemów, kreatywność menedżerów, wykorzystywanie pojawiających się szans rynkowych, skłonność do podejmowania ryzyka, umiejętność prowadzenia negocjacji. W grupie czynników, oddziałujących w mniejszym stopniu wyróżniono: efektywne wykorzystanie zasobów, tworzenie elastycznej struktury organizacyjnej firmy.

\section{TAKSONOMIA USŁUG SYSTEMOWYCH}

W latach 2008-2013 do obszarów wymagających wsparcia państwa, a tym samym wspieranych przez KSU, zalicza się usługi: a) informacyjne, b) doradcze, c) finansowe, polegające na udzielaniu pożyczek dla przedsiębiorców oraz d) finansowe, polegające na udzielaniu poręczeń przedsiębiorcom (tabela 1.).

Usługa informacyjna polega na bezpłatnym dostarczaniu informacji przedsiębiorcom oraz osobom niezbędnych przy podejmowaniu decyzji związanych z prowadzeniem działalności gospodarczej. Świadczenie tego rodzaju usług realizowane przez ośrodki KSU opiera się na zasadach ${ }^{11}$ : bezpłatności, dostępności, najwyższej jakości i rzetelności, poufności i ochrony danych

${ }^{9}$ L. H. Haber, Przedsiębiorczosí - rynkowym parametrem podmiotowości cztowieka w procesach pracy, „Humanizacja Pracy”, 1997, vol. XXX, nr 4 (178), s. 14-23, za: A. Gaweł, Ekonomiczne determinanty przedsiębiorczości, Wydawnictwo Akademii Ekonomicznej w Poznaniu, Poznań 2007, s. 23.

${ }^{10}$ U. Kłosiewicz-Górecka, Pozaekonomiczne uwarunkowania dziatań przedsiębiorczych na rynkach lokalnych, „Handel Wewnętrzny”, 2006, nr 3, s. 28.

11 Standardy ustug informacyjnych Krajowego Systemu Ustug, Departament Rozwoju Instytucji Otoczenia Biznesu, Polska Agencja Rozwoju Przedsiębiorczości. 
osobowych, wiarygodności i zaufania. Usługę informacyjną świadczą Punkty Konsultacyjne $(\mathrm{PK})$ w trzech możliwych formach: usługi bezpośredniej, usługi świadczonej drogą telefoniczną lub elektroniczną. Dodatkowo, warunkowo usługi informacyjne mogą być świadczone w formie dyżurów konsultantów poza siedzibą PK, seminariów oraz w siedzibie klienta PK.

Tabela 1. Oferta usługowa w ramach KSU

\begin{tabular}{|c|c|}
\hline USEUGI SYSTEMOWE & OFERTA USEUGOWA \\
\hline \multirow{4}{*}{ Informacyjne } & udzielanie informacji na temat dostępnych programów \\
\hline & udzielanie informacji o targach \\
\hline & kojarzenie partnerów gospodarczych \\
\hline & sprawdzanie wiarygodności partnerów handlowych \\
\hline \multirow{6}{*}{$\begin{array}{l}\text { Doradcze o charakterze } \\
\text { proinnowacyjnym }\end{array}$} & $\begin{array}{l}\text { specjalistyczne doradztwo w dziedzinie marketingu, finansów, prawa, planowania i zarzą- } \\
\text { dzania i transferu technologii, eksportu i jakości, transferu technologii, eksportu i jakości }\end{array}$ \\
\hline & podstawowe doradztwo dla osób rozpoczynających działalność gospodarczą \\
\hline & specjalistyczne, np. z zakresu marketingu, finansów i zarządzania \\
\hline & dla osób rozpoczynających działalność gospodarczą \\
\hline & branżowe \\
\hline & dopasowane do potrzeb klienta \\
\hline \multirow{2}{*}{ Finansowe } & $\begin{array}{l}\text { w zakresie udzielania pożyczek, umożliwiające uzyskanie finansowania zewnętrznego } \\
\text { przez podmioty prowadzące działalność gospodarczą }\end{array}$ \\
\hline & $\begin{array}{l}\text { w zakresie udzielania poręczeń, umożliwiające uzyskanie dodatkowego zabezpieczenia } \\
\text { kredytów lub pożyczek przez podmioty prowadzące działalność gospodarczą }\end{array}$ \\
\hline
\end{tabular}

Źródło: opracowanie własne na podstawie: Krajowy System Usług, http://ksu.parp.gov.pl, 15.05.2012; ZARR S.A., http://www.zarr.com.pl, 18.05.2012.

Rozpatrując z kolei ustugi doradcze o charakterze proinnowacyjnym należy zaakcentować, iż świadczą je konsultanci Ośrodków Krajowej Sieci innowacji (KSI). przeprowadzają w firmie analizę potencjału technologicznego oraz pomagają we wdrożeniu najlepszych rozwiązań innowacyjnych, dzięki którym przedsiębiorstwo zyska realną przewagę rynkową. Ich działania mają doprowadzić do osiągania celu usługi, jakim jest wdrożenie w przedsiębiorstwie klienta innowacyjnego rozwiązania technologicznego. Przynoszą one korzyści dla firm, nastawionych na działania innowacyjne w postaci ${ }^{12}$ : a) planu rozwoju technologii; b) łatwiejszego wdrożenia nowych technologii; c) wsparcia procesów transferu technologii specjalistyczną wiedzą; d) niższych kosztów działań proinnowacyjnych - usługi doświadczonych specjalistów są współfinansowane przez UE w ramach działania 5.2. Programu Operacyjnego „Innowacyjna Gospodarka”.

12 Fundacja Poszanowania Energii, http://fpe.org.pl, 18.05.2012. 
Ustugi finansowe polegające na uzyskaniu poręczeń realizują Fundusze Poręczeniowe, współpracujące w ramach KSU. Oferują one możliwość poręczenia pożyczek, kredytów oraz wadiów przetargowych. Wiążą się z tym określone korzyści dla przedsiębiorców ${ }^{13}$ :

- uzyskanie dodatkowego finansowania w postaci kredytu lub pożyczki na inwestycję: np. zakup maszyn, nieruchomości;

- ułatwiona procedura uzyskania poręczenia, poza złożeniem wniosku, wykonawcą formalności jest bank lub instytucja pożyczkowa;

- zabezpieczeniem poręczenia, które wymaga fundusz od przedsiębiorcy jest standardowo weksel in blanco, co pozwala na łatwe spełnienie warunku przy niewielkich kosztach.

Z kolei ustugi finansowe w zakresie pożyczek polegają na udzielaniu pożyczek na finansowanie działalności inwestycyjnej, obrotowej oraz początkowego etapu rozwoju firmy przez Fundusze Pożyczkowe współpracujące w ramach KSU. Warto przy tym zaznaczyć, iż do rozwoju sieci funduszy pożyczkowych przyczyniła się w dużej mierze Polska Agencja Rozwoju Przedsiębiorczości (PARP). Dzięki programom, realizowanym przez tę instytucję, nakierowanym na pomoc i rozwój przedsiębiorczości w Polsce organizacje prowadzące m.in. fundusze pożyczkowe mogły w nich aktywnie uczestniczyć jako beneficjenci oraz wykonawcy. Jak podaje PARP, system funduszy pożyczkowych w Polsce jest obecnie ustabilizowany. Bogata oferta produktów finansowych daje przedsiębiorcy możliwość dokonania wyboru najkorzystniejszej oferty, zarówno pod względem wysokości oprocentowania, terminu, jak i warunków spłaty, które uzależnione są w głównej mierze od źródeł finansowania poszczególnych funduszy.

Wydaje się, iż godnym podkreślenia jest faktyczny dostęp do usług systemowych w poszczególnych regionach, wyrażony w liczbie kategorii usługowych w ramach oferty ośrodków KSU (tabela 2.).

$\mathrm{Z}$ danych zawartych w tabeli 2 . wynika, że największą aktywnością pod względem świadczenia usług w ramach KSU wykazały się ośrodki Regionu Południowego, współpracujące ze sobą w w/w zakresie, zaś najmniejszą z Regionu Centralnego, co może wiązać sie ze słabym zainteresowaniem ze strony firm lub też z dostateczną samooceną odnośnie do przygotowania do prowadzenia działalności gospodarczej przez przedsiębiorców.

13 A. Banach, Zasady korzystania z ustug finansowych polegających na udzielaniu poręczeń KSU, „Przedsiębiorco! Skorzystaj”, PARP, Wyd. Naukowego Instytutu Technologii Eksploatacji PIB, PARP, Radom 2010, s. 83. 
Tabela 2. Struktura usług KSU według polskich regionów w 2010 roku (szt.)

\begin{tabular}{|c|c|c|c|c|c|c|}
\hline \multirow{2}{*}{ UStuGI SYSTEMOWE } & \multicolumn{9}{|c|}{ REGIONY } \\
\cline { 2 - 7 } & CENTRALNY & POŁUDNIOWY & WSCHODNI & $\begin{array}{c}\text { PÓŁNOCNO- } \\
\text {-ZACHODNI }\end{array}$ & $\begin{array}{c}\text { POŁUDNIOWO- } \\
\text {-ZACHODNI }\end{array}$ & PÓŁNOCNY \\
\hline Informacyjne & 22 & 38 & 33 & 29 & 13 & 32 \\
\hline Doradcze* & 38 & 48 & 42 & 39 & 20 & 39 \\
\hline Finansowe** & 7 & 14 & 14 & 9 & 5 & 10 \\
\hline Szkoleniowe & 20 & 34 & 30 & 27 & 14 & 28 \\
\hline Ochrona środowiska & 1 & 2 & 1 & 1 & 1 & 0 \\
\hline Optymalizacja kosztów & 2 & 0 & 1 & 0 & 0 & 0 \\
\hline
\end{tabular}

* wliczono usługi doradcze o charakterze ogólnym, o charakterze proinnowacyjnym, asysta;

** wliczono usługi finansowe - udzielanie, pożyczek, udzielanie poręczeń, finansowanie bezzwrotne.

Źródło: obliczenia własne na podstawie: opracowanie Departamentu Rozwoju Instytucji Otoczenia Biznesu, PARP, z dn. 13.06.2011, http://ksu.parp.gov.pl.

Z badań PARP wynika, że przedsiębiorcy z Regionu Centralnego istotnie częściej oceniają ogólną sytuację firmy jako dobrą (72,9\%). Prawdopodobnie wynika to z bliskości stolicy, przez co region rozwija się szybciej w porównaniu do reszty kraju. Stołeczny region jest siedzibą przedstawicielstw wielu firm zagranicznych i polskich, co powoduje wzrost liczby zatrudnionych, a także daje większe możliwości współpracy między przedsiębiorstwami. Przedsiębiorсу z Regionu Południowego oraz Południowo-zachodniego istotnie rzadziej wskazywali, że kondycja ich przedsiębiorstw jest dobra - odpowiednio 42,1\% i $41,6 \%{ }^{14}$.

Biorąc pod uwagę liczbę usług informacyjnych (tabela 2.), na tle regionów wyróżniły się ośrodki regionów: południowego i wschodniego, najmniejszą intensywnością w tej kategorii wyraźnie wykazał się region południowozachodni. Największe znaczenie przypisano usługom doradczym, najmniejsze - usługom związanym optymalizacją kosztów prowadzenia działalności gospodarczej dla MSP.

W ramach KSU usługi systemowe świadczone są przez 18 ośrodków w zakresie usług doradczych o charakterze proinnowacyjnym, 96 ośrodków w zakresie usług informacyjnych, świadczących usługi w około 300 lokalizacjach, 10 ośrodków w zakresie usług finansowych - udzielanie poręczeń, 38 ośrodków w zakresie usług finansowych - udzielanie pożyczek ${ }^{15}$.

${ }^{14}$ Raport z badania „Wizerunek Krajowego Systemu Usług” na zlecenie Polskiej Agencji Rozwoju Przedsiębiorczości, Warszawa, listopad 2011, http://ksu.gov.pl, 08.06.2012.

${ }_{15}$ Informacja na temat Krajowego Systemu Ustug (KSU), rozdział 1: Przedsiębiorco! Skorzystaj, Wyd. Naukowego Instytutu Technologii Eksploatacji - PIB, PARP, Warszawa 2010, s. 10. 
Porównując regiony (wykres 1.) o zbliżonej ogólnej liczbie ośrodków KSU i małej liczbie województw z regionami o dużej liczbie województw, np. centralny ze wschodnim, można zauważyć, iż w regionie centralnym na 31 instytucji świadczących usługi KSU aż 19 przypada na województwo mazowieckie, 12 - na łódzkie. W regionie wschodnim natomiast z ogólną liczbą ośrodków KSU 38, w woj. podkarpackim znajduje się 12, najmniej - w lubelskim 8, podlaskiemu oraz świętokrzyskiemu przypadło po 9 instytucji.

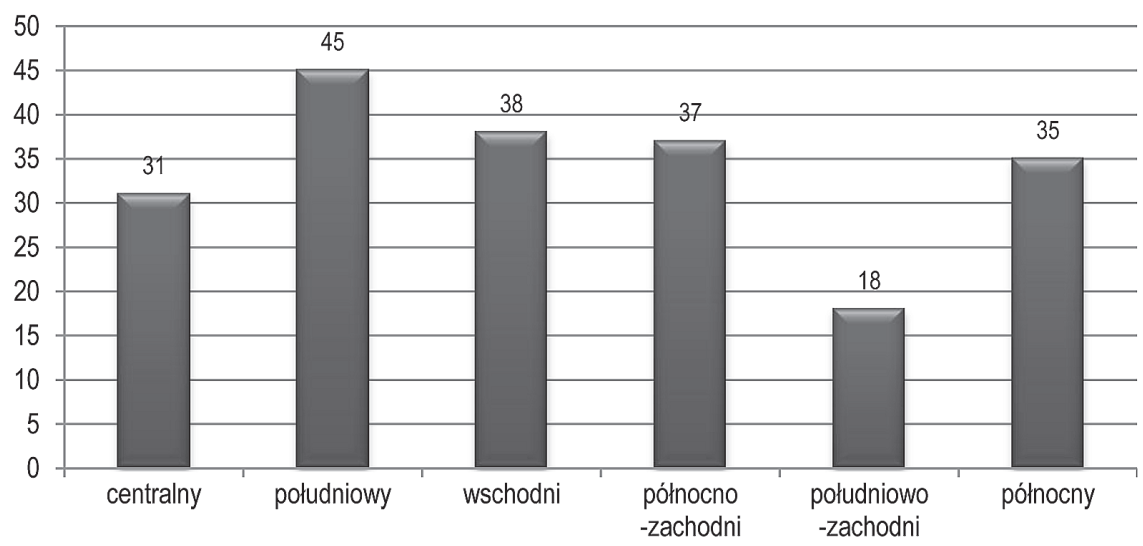

Wykres 1. Liczba instytucji współpracujących w KSU w podziale na polskie regiony (szt.) Źródło: obliczenia własne na podstawie: Lista ośrodków KSU, http://ksu.parp.gov.pl, 08.06.2012.

Nierównomierne przyporządkowanie województw do poszczególnych regionów Polski narzuca niejako określoną liczbę ośrodków lokalnych działających w ramach Krajowego Systemu Usług. Ich liczba może, jak się wydaje, być związana ze zgłaszanymi potrzebami przez mikro-, małe i średnie przedsiębiorstwa. I tak, najwięcej ośrodków realizujących usługi KSU znajduje się $\mathrm{w}$ regionie południowym, w tym województwo śląskie obejmuje 32 ośrodki oraz małopolskie - 13, a najmniej ich działa w regionie południowo-zachodnim, w ramach którego dolnośląskiemu przypisano - 12, opolskiemu - 6 .

\section{3. ŚWIADCZENIE USŁUG A POTRZEBY PRZEDSIĘBIORCÓW W REGIONIE}

Przedsiębiorczość jako proces nie jest zjawiskiem statycznym, wiąże się ze zmianami. Dlatego też istotne jest znalezienie nowych kombinacji czynników produkcji w dążeniu do stworzenia potencjału. I tak, na poziomie przestrzennym podstawowym jej celem jest stworzenie kompleksowej i zrów- 
noważonej strategii lokalnej, która będzie osadzać działalność gospodarczą $\mathrm{w}$ danym obszarze ${ }^{16}$.

Strategie dotyczące lokalnego rozwoju przedsiębiorczości zwykle skupione są wokół czterech głównych osi: 1) poprawa konkurencyjności lokalnych firm, 2) przyciaganie inwestycji zagranicznych, 3) modernizacja kapitału ludzkiego lub umiejętności pracy, 4) budowa infrastruktury.

Zgodnie $\mathrm{z}$ wynikami badań na zlecenie $\mathrm{PARP}^{17}$, za największą zaletę Krajowego Systemu Usług uznano świadczenie pomocy przedsiębiorcom oraz osobom planującym założenie działalności gospodarczej - 52,2\% respondentów. Ponadto do atutów KSU zalicza się kompleksowość usług, wysoką jakość usług, dostępność ${ }^{18}$. Do wad KSU zalicza się: brak ogólnodostępnych informacji na temat KSU - 61\%, zbyt skomplikowane procedury, co wiąże się ze zniechęceniem przedsiębiorców do korzystania $\mathrm{z}$ ofert sieci wspierających przedsiębiorczość - $12,5 \%$, zbyt szeroką ofertą darmowych usług, zniechęcającą do skorzystania $\mathrm{z}$ oferty KSU zaliczono z kolei do wad KSU ${ }^{19}$.

Wobec powyższego, przedsiębiorcy określili obszary działalności, w których potrzebowaliby wsparcia (wykres 2.).

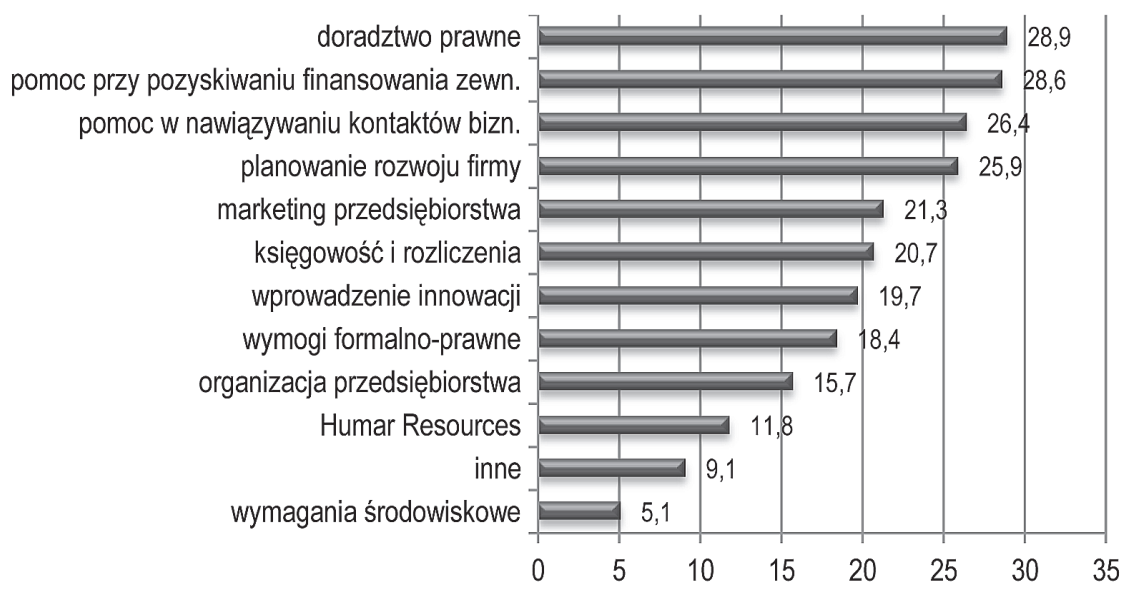

Wykres 2. Zgłaszane potrzeby wsparcia według obszarów działalności (\%) Źródło: Raport z badania „Wizerunek Krajowego...

${ }^{16} \mathrm{R}$. Mustafa-Topxhiu, The role of entrepreneurship and enterprisesfor local economic development, „Academicus - International Scientific Journal”, June 1, 2012, Issue 5, s. 96-107.

17 Raport z badania „Wizerunek Krajowego...

18 Ośrodek Krajowego Systemu Usług dla Małych Średnich Przedsiębiorstw ZARR S.A., http://www.zarr.com.pl, 18.05.2012.

19 Raport z badania „Wizerunek Krajowego... 
Zgodnie z zestawieniem potrzeb najbardziej pożądanych przez przedsiębiorców, najwięcej osób wskazało doradztwo prawne (29\%) oraz pomoc przy pozyskiwaniu finansowania zewnętrznego (kredytów, pożyczek). Najmniejszym zainteresowaniem respondentów cieszyłoby się wsparcie dotyczące wymagań środowiskowych (5\%). Co dziesiąty przedsiębiorca wskazał na inne obszary, w których chciałby otrzymać wsparcie, np. pomoc przy ubieganiu się o dotacje unijne ${ }^{20}$.

Niedopasowanie oferty usługowej instytucji świadczących usługi w ramach Krajowego Systemu Usług do potrzeb zgłaszanych przez polskich przedsiębiorców z sektora MSP stanowi wyzwanie dla instytucji, mających na celu rozwój przedsiębiorczości (tabela 3.).

Tabela 3. Zestawienie potrzeb usługowych polskich przedsiębiorców z ich zaspokajaniem w KSU

\begin{tabular}{|c|c|c|}
\hline RODZAJE UStUG SYSTEMOWYCH & OFERTA UStUGOWA OŚRODKÓW KSU (SZT.) & ZGtASZANY ODSETEK POTRZEB (\%) \\
\hline Doradcze & 226 & $0 \mathrm{k} .80^{*}$ \\
\hline Informacyjne & 167 & 26,4 \\
\hline Szkoleniowe & 153 & 11,8 \\
\hline Finansowe & 59 & 28,6 \\
\hline Ochrona środowiska & 6 & 5,1 \\
\hline Optymalizacja kosztów & 3 & $28,9^{\star \star}$ \\
\hline
\end{tabular}

* włączono różne rodzaje usług doradczych;

** doradztwo prawne $-28,9 \%$.

Źródło: opracowanie własne na podstawie danych: Lista ośrodków KSU, http://ksu.parp.gov.pl, 08.06.2012; Raport z badania „Wizerunek Krajowego...

$\mathrm{Na}$ podstawie danych z tabeli 3. można zauważyć, że istnieją obszary działalności wymagające wsparcia. Wyraźnie dotyczą one potrzeb związanych z doradztwem prawnym, które potraktowano odrębnie od wymogów formalno-prawnych prowadzenia działalności gospodarczej.

\section{ZAKOŃCZENIE}

Reasumując należy stwierdzić, iż znaczenie usług systemowych świadczonych w ramach KSU dla rozwoju przedsiębiorczości regionalnej nie jest aktualnie przesądzone, gdyż relatywnie niewielu przedsiębiorcom udaje się skorzystać z oferty ośrodków świadczących wspomniane usługi oraz tylko część z nich odczuwa potrzebę bycia ich odbiorcami. Nie ulega jednak wątpliwości,

${ }^{20}$ Ibidem. 
że usługi systemowe stanowią nowoczesne środki rozwoju przedsiębiorczości oraz ważną pomoc polskim przedsiębiorcom, którzy mogą korzystać z fachowej wiedzy z zakresu gospodarki i innowacji oraz pożyczek i poręczeń kredytowych. Osoby prowadzące działalność gospodarczą mają więc szansę na jakościową transformację przedsiębiorstwa. Chociaż przedsiębiorczość dotyczy poziomu indywidualnego, to realizacja przedsięwzięcia następuje na poziomie firm.

Jak wynika z założenia Krajowego Systemu Usług PARP, poprzez usługi systemowe następuje rozwój koordynacji wspólnych działań na rzecz promocji przedsiębiorczości z polskimi regionami. Zaangażowanie samorządu terytorialnego ma dzięki temu znaczący wpływ na rozwój gospodarczy w swoim regionie. Warto przy tym podkreślić, że występuje w znacznym stopniu brak zgodności potrzeb przedsiębiorców $\mathrm{z}$ ofertą usługową KSU, a procedury korzystania $\mathrm{z}$ ofert sieci wspierających przedsiębiorczość są nadto skomplikowane. Można więc postulować pod adresem instytucji rządowej oraz ośrodków wyspecjalizowanych w ramach KSU o szerszy wachlarz informacji oraz wzmocniony system popularyzowania możliwości usługowych, przy równocześnie jasnym i łatwym dostępie do każdego z rodzajów usług KSU, umożliwiającym powstawanie oraz rozwój małych, średnich i mikroprzedsiębiorstw we wszystkich regionach Polski.

\section{BIBLIOGRAFIA}

Arkusz informacyjny SBA - Polska - 2010/2011, http://ec.europa.eu, 04.05.2012.

Banach A., Zasady korzystania z ustug finansowych polegajacych na udzielaniu poręczeń $K S U$, „Przedsiębiorco! Skorzystaj”, PARP, Wyd. Naukowego Instytutu Technologii Eksploatacji - PIB, Radom 2010.

Bank danych lokalnych, Główny Urząd Statystyczny, http://www.stat.gov.pl, 09.06.2012. Drucker P. F., Natchnienie i fart, czyli innowacja i przedsiębiorczość, Wyd. Studio EMKA, Warszawa 2004.

Fundacja Poszanowania Energii, http://fpe.org.pl, 18.05.2012.

Haber L. H., Przedsiębiorczość - rynkowym parametrem podmiotowości cztowieka w procesach pracy, „Humanizacja Pracy”, 1997, vol. XXX, nr 4 (178), s. 14-23, za: A. Gaweł, Ekonomiczne determinanty przedsiębiorczości, Wydawnictwo Akademii Ekonomicznej w Poznaniu, Poznań 2007.

Informacja na temat Krajowego Systemu Ustug (KSU), rozdział 1: Przedsiębiorco! Skorzystaj, PARP, Wyd. Naukowego Instytutu Technologii Eksploatacji - PIB, Radom 2010.

Jagiełło A., Region i jego rozwoój w warunkach globalizacji, [w:] Błaszczuk D. J., Stefański M. (red.), Strategiczna problematyka rozwoju Polski Wschodniej, Wyższa Szkoła Ekonomii i Innowacji w Lublinie, Lublin 2010. 
Kłosiewicz-Górecka U., Pozaekonomiczne uwarunkowania działań przedsiębiorczych na rynkach lokalnych, „Handel Wewnętrzny”, 2006, nr 3.

Krajowy System Usług, Polska Agencja Rozwoju Przedsiębiorczości, http://ksu.parp. gov.pl, 15.05.2012.

Newbert S. L., New Firm Formation: A Dynamic Capability Perspective, "Journal of Small Business Management", 2005, vol. 43 (1), http://dx.doi.org/10.1111/j. 1540-627X.2004.00125.x.

Ośrodek Krajowego Systemu Usług dla Małych Średnich Przedsiębiorstw ZARR S.A., http://www.zarr.com.pl, 18.05.2012.

Raport z badania „Wizerunek Krajowego Systemu Usług” na zlecenie Polskiej Agencji Rozwoju Przedsiębiorczości, Warszawa, listopad 2011, http://ksu.gov.pl, 08.06.2012.

Standardy ustug informacyjnych Krajowego Systemu Ustug, Departament Rozwoju Instytucji Otoczenia Biznesu, Polska Agencja Rozwoju Przedsiębiorczości, http:// ksu.parp.pl, 05.06.2012.

Zeman-Miszewska E., Przeksztatcenia instytucji regionalnych/lokalnych w Polsce (wybrane problemy), [w:] Okoń-Horodyńska E. (red), Przedsiębiorczoś́ jako niewwykorzystane źródto sukcesu polskiej gospodarki, Polskie Towarzystwo Ekonomiczne, Warszawa 2009. 